\title{
Overview of World Planning Trends and Land Use Planning in a Sustainable Way in Vietnam
}

\author{
Ngoc Dan Nguyen \\ Institute of Land Management \\ Northeastern University \\ Shenyang, China 110169
}

\author{
Guoping Lei \\ Institute of Land Management \\ Northeastern University \\ Shenyang, China 110169
}

\author{
Xuan Minh Tran \\ Institute of Land Management \\ Northeastern University \\ Shenyang, China 110169
}

\begin{abstract}
Planning of appropriate land use, forest restoration and land protection are fundamental environmental factors for sustainable development in the agroforestry sector. This article attempts to address some of the world planning trends and to study land use planning in the context of sustainable development in Vietnam. Propose planning methods at different levels and develop an action plan for land use planning in Thua Thien Hue province as illustrated.
\end{abstract}

Keywords-land use planning; land; sustainable development

\section{INTRODUCTION}

In the present stage, economic development is coupled with the exploitation of natural resources, especially land resources, causing degradation, depletion of natural resources and strong impacts on the environment. It is now imperative to make land use planning, forest restoration and land protection. This contributes to the settlement of territorial organization and socio-economic development of local areas and region-also contributes to "sustainable development". There is still a current situation of spatial planning apart from socio-economic development planning, planning at all levels, unconnected sectors, rigid planning schemes, long time for preparation and approval of planning and poor planning implementation capacity, therefore, the planning feasibility not high, the development practice is separate from planning. In the face of these challenges, many innovative ideas aimed at redirecting spatial planning are debated and heatedly discussed in international and national forums, many of which have been accepted by a majority of states into use in the new century, initially brought good results. This article attempts to address some of the planning trends in the world and to study land use planning in the direction of sustainable development in Vietnam. In order to be able to effectively make land use planning, it is first necessary to clearly define the contents and level of land use planning. On the other hand, it is necessary to obtain scientific databases, management of information on land fully, accurately, timely and regularly updated. Thus, it is possible to put forward solutions and rational decisions in the process of formulating socio-economic development strategies, setting up reasonable land use measures and protecting the environment.

\section{OVER VIEW OF WORLD PLANNING TRENDS}

\section{A. Roles and Objectives of the Planning}

Today's spatial planning is not simply the geographical representation of development strategies and policies through efficient and orderly allocation of land use, but also as a very important governance tool to effectively mobilize all resources, participation, public-private partnerships and make effective investment decisions, etc., and, in accordance with the SRU law, meet 03 requirements:

- unity;

- sustainable development;

- Consolidation of democracy and decentralization.

In the same way, the United Nations Economic Commission for Europe sets out five general objectives of spatial planning [1]:

- Promoting democratic governance system that meet the needs of local communities;

- Improving the urban environment;

- Facilitating cohesion and social security;

- Promoting market reforms in the housing and urban areas;

- Completing land and real estate markets, securing private rights to land. Facing serious environmental pollution and the threat of climate change, the thinking of sustainable development is becoming 
more and more powerful, therefore, the Strategic Environment Asessment (SEA) is highly appreciated in the planning.

\section{B. Method of Planning}

Planning thinking in the past was too critical of the legal functions over development functions of the spatial planning, wished to connect all development activities to the law, eliminate every informal development, therefore, it is too rigid, not practical and not feasible [2]. Today's national development practice is fast changing, therefore, it is necessary to reform the method of planning to better and better adapt. In the 21 st Century, many states have made fundamental reforms of the planning system in more inclusive, flexible, democratic and sustainable ways, namely:

- Make better coordination of sectoral activities;

- Be more flexible in the planning process;

- Make greater accountability in the implementation of the planning;

- Make more effective participation of local communities and stakeholders;

- Make collection of development fees to offset externalities and supplement the benefits to local communities;

- Take greater responsibility for the environmental impact of the planning. Today's planning methods use a variety of new approaches, such as a comprehensive approach, an integrative approach, and a strategic approach.

1) Comprehensive approach: A comprehensive planning approach to integrate socio-economic development planning with spatial planning has been adopted by many states but is new to the states that are transitioning to the market economy like the old Eastern European countries or Vietnam, China, and even some developing countries like Indonesia. That is because in the centrally planned economy, the state first needs to come up with a socio-economic development plan, usually within five years, for the authorities to operate all development activities, including spatial planning. But when it comes to competitive economy, the government can not put forward such rigid development planning targets but can justify development forecasts and directions, therefore, there is no need but also it is not possible to separate two development plan and spatial planning, thus reforming the planning legal framework to integrate them into a comprehensive approach. Many countries also refer to an integrated planning approach that integrates many separate plannings into one body in order to overcome the local phenomenon of ministries, especially in the infrastructure sectors, gather development planning/policies of sectors into the same spatial plan. Thus, the concept of integrated planning and comprehensive planning is not far apart: the comprehensive planning must include integrated planning. Although comprehensive planning is widely applied, it has revealed some limitations, such as the planning process and the planning approval, which are often lengthy and require a lot of data. There is a certain delay that makes planning difficult to keep up with the realities of development even though it is amended in the process of implementation! In practice, it is very difficult to completely eliminate the unofficial development. There is also a great challenge in that the planning of place involves a variety of complex institutions and fields that need to be dealt with. In the meantime, a master planning, usually called as a master plan, is just a product made by planning specialists towards the ideal goals, after it is approved by the competent agency, the governmental authority is responsible for organizing and managing the rigid implementation. This traditional approach to planning has been somewhat effective in the slow progressive stages of development, but today, as the rate of economic development and urbanization becomes more rapid and global competitiveness is stressful, networking network is gradually formed in the society, climate change is unpredictable, etc., many countries have turned to strategic planning approach. [3].

2) Strategic planning approach: In order to overcome these said enormous challenges, policymakers find it necessary to emphasize long-term thinking and become increasingly aware that the development of planning schemes may not be the main purpose of the planning, but the planning that is not implemented is of no value. They conclude that planning should be more flexible and linked to urbanism, in addition to the "top down" approach, adding "bottom up," and finding the solutions for the questions is the "strategic spatial planning approach," defined by Louis Albrechts as "a transformative and integrated process directed by the public sector but about production - society - space, and then giving vision/framework for reference, providing a demonstration of consistent actions and measures to show the shape and size that a place is or may have " [4]. This definition will become easier to understand with the typical table of traditional planning and strategic planning in "Table I" mentioned below: 
TABLE I. TyPICAL TABLE OF TRADITIONAL PLANNING AND STRATEGIC PLANNING

\begin{tabular}{|l|l|}
\hline \multicolumn{1}{|c|}{ Traditional planning } & \multicolumn{1}{c|}{ Traditional planning } \\
\hline Toward products (scheme) & Towards Process and Action \\
\hline Get started by statutory powers & Get started by agreeing on topics \\
\hline Responsive & Proactive \\
\hline Comprehensive mentioning & Selective \\
\hline Significant quantitative analysis & Appreciate intuition and vision \\
\hline Do not consider the values & Appreciate values, organization \\
\hline $\begin{array}{l}\text { Don not consider strengths and } \\
\text { weaknesses }\end{array}$ & $\begin{array}{l}\text { Analyze the } \\
\text { weaknesses }\end{array}$ \\
\hline Interact with the data & Interact with interested parties \\
\hline Administrative Orientation & Recognize and enter politics \\
\hline Believe in performance capacity & Consider performance capacity \\
\hline $\begin{array}{l}\text { Separate the planning from } \\
\text { mobilization and allocation of } \\
\text { funds }\end{array}$ & $\begin{array}{l}\text { Towards the allocation } \\
\text { organizational resources }\end{array}$ \\
\hline $\begin{array}{l}\text { Planning does not take into } \\
\text { account adverse situations }\end{array}$ & $\begin{array}{l}\text { Planning covers } \\
\text { situations }\end{array}$ \\
\hline $\begin{array}{l}\text { Vision toward the ideal ending } \\
\text { Planning experts prepare the } \\
\text { planning in charge }\end{array}$ & $\begin{array}{l}\text { Commit to develop vision } \\
\text { through interaction } \\
\text { the planning with assistance by } \\
\text { planning experts }\end{array}$ \\
\hline $\begin{array}{l}\text { Implement the planning under the } \\
\text { directive }\end{array}$ & $\begin{array}{l}\text { Implement the planning by } \\
\text { empowerment }\end{array}$ \\
\hline
\end{tabular}

3) Renovation in the management of planning implementation: The strategic planning has integrated the preparation and implementation of planning into a process, the object in charge of preparing the planning is also one in charge of implementing the planning, and as mentioned above, the planning is a governance tool, as well as implementing. In order to do so, the planning must come up with a clear "Planning Proposals" system, and the governmental authorities, based on them, will issue a "Program for Implementation" or Action Plan, with clear assignment and decentralization of responsibility for implementing planning recommendations with spatial scope and time of determination. The development of a framework of legal and institutional policies for the implementation of the planning at each level is essential for successful implementation of the planning. Taking land for implementing the planning is a difficult issue for the governmental authorities, especially for developing countries. Many developed countries alongside the compulsory purchase and preemption of land in the public interests have applied land pooling method whereby property owners in the project development area organize self-negotiation, contribute land to the project, and enjoy equal benefits. Many of the new financial instruments used by the governmental authorities to fund infrastructure works in expected development area [5]. One challenge in the regional planning is that many regions do not have the corresponding level of governmental authorities, therefore, many countries adopt the Regional Development Council system, which is a self-governing institution established by the administrative levels in the region and acting as chairman in turn. During the implementation of the planning, the organization of "Monitoring and Evaluation" (M \& E) independently is very important, which should be incorporated into many legal framework.

\section{CONTENT AND METHODS OF LAND USE PLANNING IN VIETNAM}

\section{A. Content}

1) Land use planning: According to FAO's definition, land use planning involves a systematic assessment of soil and water potential, land use patterns, land use abilities and other socio-economic conditions, in order to select and adopt land use options most beneficial for users without undermining natural resources or the environment, at the same time to identify the best way to promote such use of land.

Land use planning aims to select and adopt modes of land use that best meet human needs while sustaining resources for the future generations. Land use planning can take place at many levels and in different spheres like: international, national, regional, provincial, district and communal levels. In Vietnam, land use planning is conducted from national to communal level, engaging multilevel management bodies, land users, planners, local authorities and bodies and involving legislative, financial and educational measures and policies.

2) Content of land use planning:

- Systematic evaluation of land according to use purpose and land potential, assessment of economic and social conditions. In fact, climate, vegetation, hydrology and soil types (soil properties and quality, soil classification) must be taken into account. Moreover, consideration should be paid to the potential for cultivation and land use of labours and landowners as well as the current land use status. Facilities and economic development level of the community and funds for production should also be considered.

- Selection and proposal of optimal land use patterns, types and modes for a specific land unit taking into account natural, socio-economic conditions as well as future trends of environment and land protection.

The content of land use planning must cover three objectives including efficiency (economic development), environmental sustainability (flow regulation, soil protection against erosion, biodiversity) and social stability.

\section{B. Methods of Land Use Planning}

- Setting goals, requirements and tasks: Based on the current situation, identify the needs (of local people and local government). Determine the level of planning, given the agreed goals, requirements and objectives. Assign responsibilities for project implementation.

- Organizing the work: Address what to do and activities to undertaken; choose task groups; plan the performance and expected results; ensure the 
performance of each group implementing the tasks or participating in plans making.

- Analyzing problems: research on the current land use situation, including field survey, discuss with land users and identify their land use requirements and perspectives; address incurring problems and analyze causes; identify bottlenecks so as to change the current situation.

- Identifying opportunities for change: identify and preliminarily propose feasible land use patterns to achieve the goals of a land use plan; present and discuss these patterns with the public.

- Evaluating land adaptability: Set up land demand and land potential for each pattern of land use projected. Based on soil properties, assess the natural (potential) adaptability of the soil to land use patterns.

- Evaluating land use plans upon socio-economic and environmental analysis: Assess socio-economic and environmental impacts to the land users as well as the entire community for each match of natural adaptability and land use pattern. List potential consequences, appropriateness and inappropriateness of each land use plan.

- Choosing the best plan: Organize discussions and conferences on land use plans, discuss the effects of each plan. Based on these discussions and the above analysis (step 6), decide which change on land use should be made or intended to be implemented.

- Preparing land use plans: Set up appropriate plan on land use management and planning for the selected area. The plan must reflect the intended improvements, how it is put into practice, imply guidelines on financing solutions and policies if needed; while the preparation of plan should involve decision makers, managers, relevant economic sectors and land users.

- Implementing the plan: This may be done straight away or in a more prudent manner through individual planning projects. When implementing the plan, the planning team should coordinate with the executors.

- Monitoring and reviewing the plan: Monitor the implementation of the plan following the intended objectives; revise or review the plan using acquired experiences.

The above steps can be disposed into 4 sequential groups as follows: Address problems to be solved (steps 1-3); Identify plans to solve the problems (steps 4-6); Decide the best plan and prepare the plan (steps 7-8); Implement the plan, monitor, adjust and grasp lessons (steps 9-10).

\section{RESULTS AND DISCUSSION}

\section{A. Macro Planning}

This is the most all-embracing level of planning. The main task is to determine the land fund structure by use or purpose: Special-use forest land, protection forest land and production land (agricultural land and forestry land). Land fund structure determination is immensely important in directing local agro-forestry development, which in turn lays the basis for optimal layout of production and production stability and development. This level of land use planning requires information about the current area of agricultura land, documents on special-use zones, documents concerning local natural and socio-economic conditions and agroforestry development strategies. Maps are usually scaled at 1:100,000 (at provincial level) or 1:50,000 (at district level).

\section{B. Micro Planning}

This level requires land use planning to be taken at a deeper perspective to identify patterns of land use. As prescribed in the Land Law 1998 (as supplemented), there are six main patterns of land use:

- Agricultural land including land for cultivation, husbandry \& aquaculture, land for nursery, annual crops and perennial crops.

- Forestry land including forest land (natural forests, planted and regenerated forests) and land planned for afforestation, rehabilitation and forestry purposes (grassed vacant land IA, vacant land with bushes IB and vacant land with scattered trees IC).

- Urban land including land for housing construction.

- Rural land including land for housing construction, residential land of rural residents and gardens.

- Special-use land refers to the areas outside agricultural, forestry and residential land, including land for of industrial parks, scientific and technique research facilities, land for road construction, exploitation of minerals \& building materials, cultural and historical relics, and so on.

- Unused land refers to areas not yet put into agricultural or forestry production and yet to be cleared for construction of residential areas, cities or other specialized purposes. These land areas are under the State's management.

Depending on particular land use situations, the above land categories can be subdivided into smaller groups for easier monitoring of land use potential as well as monitoring and evaluation of area variation among different patterns of land use. These patterns of land use are constantly changing due to the socio-economic movements. Land use plans are usually formulated every five to ten years (at the provincial level). Information that is needed for micro land use planning includes the current area of land use patterns, territorial structure of land use, the use trends and fluctuation of land categories. Land use map is scaled at 1:100,000 (provincial 
level), 1:50,000 (district level) and 1:25,000 or $1: 10,000$

(commune level) as in "Fig. 1".

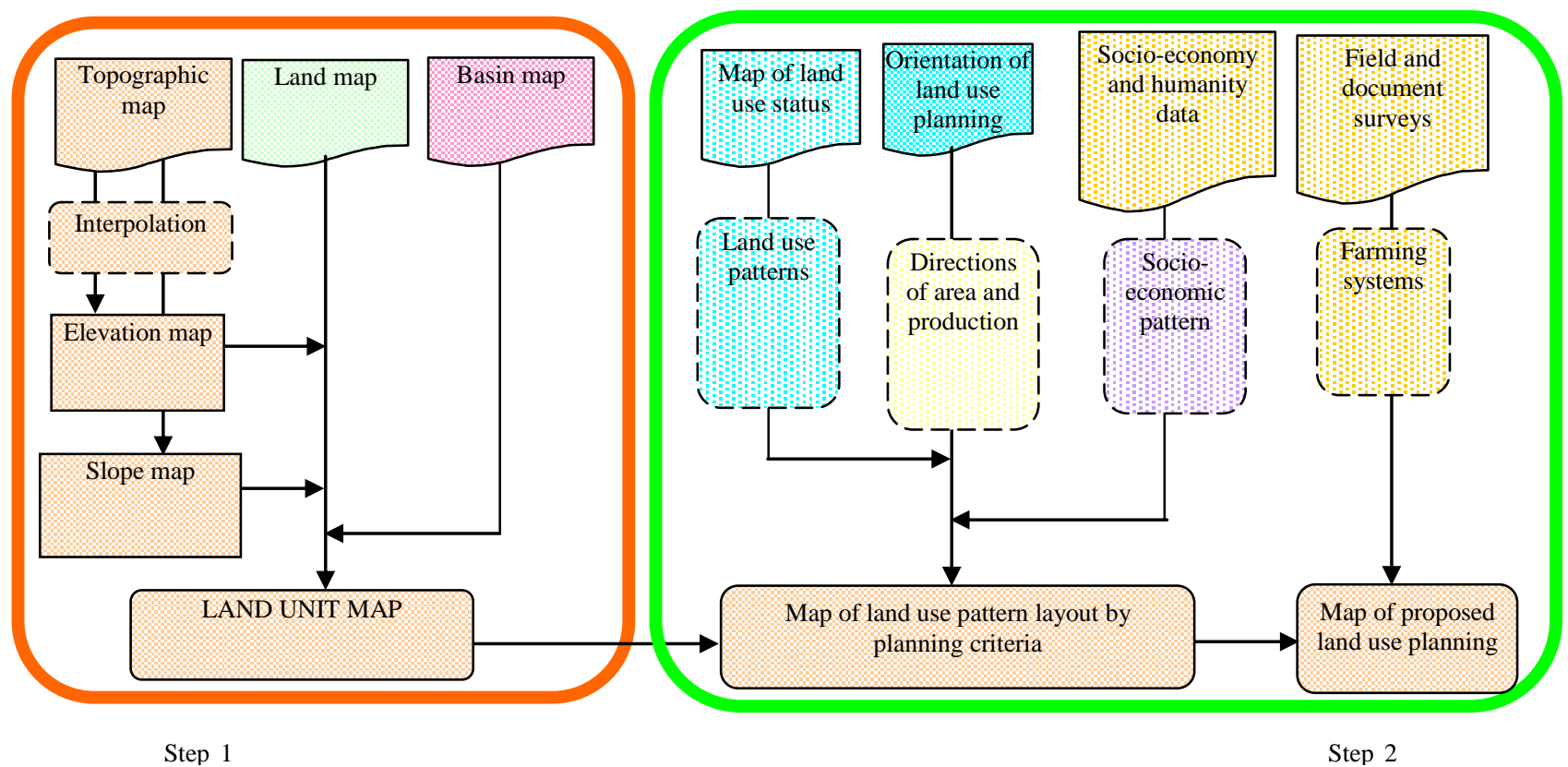

Fig. 1. Diagram of land use planning steps in Thua Thien Hue Province.

\section{Identification of Farming Model}

This method, involving a detailed planning, often applies to small areas. It focuses on building integrated agro-forestry production models while harmonizing all three aspects of benefits (economical - social - ecological environment). Choices maybe taken among the following, depending on the local natural, social and economic conditions: general integrated agro-forestry; integration of agro-forestry and husbandry; integration of agro-forestry and fishery; integration of forestry and husbandry, or integration of agroforestry, fishery and tourism, etc. The main issue of concern is to select the right structure of crops and animals to be applied in the production model. Crops may include: protection plants, perennial industrial crops, short-term industrial crops, food crops and legumes. Short-term crops are often intercropped with two rows of perennial plants or cultivated under the forest canopy. Livestock must be adaptive, thus reducing initial investment and enabling the ecosystem regeneration and sustainability. Planning maps are generally scaled at 1:25,000; 1:10,000 or 1:5,000, 1:2,000.

\section{CONCLUSION}

Determining the content and level of land use planning plays an important part in land use strategy for a territorial unit. Land use status analysis, land adaptability assessment, and environmental and socio-economic impacts assessment should be conducted based on the local goals, requirements and needs, so as to define the most appropriate land use plan.

The selected land use plan should achieve the main objectives of effectiveness - sustainability and social stability.

\section{REFERENCES}

[1] Nguyen Thi Kim Chuong, Dao Khang, Methods to assess land use potential for various forms of agro-forestry in Nghe An highlands and mountains, Scientific notices of universities. Biology-Agriculture, Hanoi, 1999.

[2] Ministry of Agriculture and Rural Development, Agricultural Land evaluation Procedure, Hanoi, Agriculture Publishing House, 1999.

[3] FAO, A Framework for land evaluation, International Institute for land reclamation and improvement, 1976.

[4] FAO, Guidelines for land-use planning. Rome, 1993.

[5] Doan Cong Quy, 2004, Textbook of Land Use Planning, Hanoi Publishing House. 197 pages

[6] FRESCO L.O, H.G.J. HUIZING, H. VAN KEULEN, H.A. LUING AND R.A. SCHIPPER, 1993. Land evaluation and farming system analysis for land useplanning. FAO/ITC/Wageningen Agricultural University. FAO workingdocument. 200p

[7] Ministry of Agriculture and Rural Development, Agricultural Land evaluation Procedure, Hanoi, Agriculture Publishing House, 1999. 